ISSN 1392-3196 / e-ISSN 2335-8947

Zemdirbyste-Agriculture, vol. 107, No. 4 (2020), p. 367-372

DOI $10.13080 /$ z-a.2020.107.047

\title{
Planting distance affects apple tree growth, fruit yield and quality
}

\author{
Nobertas USELIS ${ }^{1,3}$, Jonas VIŠKELIS ${ }^{1}$, Juozas LANAUSKAS ${ }^{1}$, Mindaugas LIAUDANSKAS ${ }^{1,2}$, \\ Valdimaras JANULIS ${ }^{2}$, Darius KVIKLYS ${ }^{1,4}$ \\ ${ }^{1}$ Lithuanian Research Centre for Agriculture and Forestry, Institute of Horticulture \\ Kauno 30, Babtai, Kaunas distr., Lithuania \\ E-mail: darius.kviklys@lammc.lt \\ ${ }^{2}$ Lithuanian University of Health Sciences, Faculty of Pharmacy \\ Sukilèlių 13, Kaunas, Lithuania \\ ${ }^{3}$ Vytautas Magnus University Agriculture Academy \\ Studentų 11, Akademija, Kaunas distr., Lithuania \\ ${ }^{4}$ Norwegian Institute of Bioeconomy Research - NIBIO Ullensvang \\ 5781 Lofthus, Norway
}

\begin{abstract}
A study on the influence of planting distances on the growth, productivity and fruit quality of dwarf apple trees in a 15- to 18-year-old orchard was carried out at the Institute of Horticulture, Lithuanian Research Centre for Agriculture and Forestry. Trees of the apple (Malus $\times$ domestica Borkh) cultivar 'Auksis' on rootstock P 60 were planted at distances of $3 \times 1.5,3 \times 1.25,3 \times 1.00 \mathrm{~m}$ and $3 \times 0.75 \mathrm{~m}$. With increasing density of fruit trees, singletree growth, generative development and yield were significantly reduced. The opposite results were obtained when these parameters were evaluated per unit area. Yield and fruit quality measurements were made at two canopy heights: $0-1.5$ and $1.5-2.5 \mathrm{~m}$. In the upper part of the fruit tree canopy, fruit average weight and diameter were higher, while the colour was more intense and less dependent on the planting density of fruit trees. In the lower part of the canopy, fruit quality was inferior and with increasing fruit tree density it further deteriorated. Planting distances had a significant effect on the accumulation of sugar, soluble solids and dry matter content: greater planting distances resulted in increased sugar content from $10.97 \%$ to $11.90 \%$, soluble solids - from $12.30 \%$ to $13.17 \%$ and dry matter content - from $13.80 \%$ to $14.80 \%$. Conversely, higher accumulation of phenolic and triterpenic compounds in apple fruits was found with decreasing planting distances. A significant increase of phenolic compounds from 2.91 up to $4.03 \mathrm{mg} \mathrm{g}^{-1} \mathrm{DW}$ (dry weight) was recorded at the upper part of the canopy, while an increase of triterpens from 12.9 up to $16.07 \mathrm{mg} \mathrm{g}^{-1} \mathrm{DW}$ - at the lower part of the canopy. The best productivity and fruit quality of 'Auksis' apple trees on $\mathrm{P} 60$ rootstock at the full bearing stage were obtained, when fruit trees had been spaced at $3 \times 1.25 \mathrm{~m}$.
\end{abstract}

Key words: fruit biochemical composition, fruit colour, Malus $\times$ domestica, planting system.

\section{Introduction}

To remain competitive in the fruit-growing business, many countries have switched to intensive dwarf apple orchards. Dwarfing rootstocks have been the key to the dramatic changes in tree size, spacing and early production (Robinson, 2007 a). In the regions with colder winters, fruit trees with rootstocks P 60 and B.396 are most commonly used for establishing apple orchards. They have similar rootstock M 9 growth and productivity characteristics but are more winter hardy (Kviklys et al., 2016). Commercial dwarf orchards planted with these rootstocks and winter-hardy cultivars have a long-lasting productive life, even in northern climate conditions.

A more compact fruit tree is more efficient at intercepting the sun's energy (Green et al., 2003). In the countries with a developed fruit growing sector, the optimum number of dwarf fruit trees is estimated at 2500-3300 trees ha ${ }^{-1}$ (Platon et al., 2014; Robinson et al., 2014; Lordan et al., 2019).

The main aim of modern commercial orchards is to produce more high-quality fruits suitable for fresh consumption. This goal help achieve the right rootstockscion combination, canopy shape and optimal orchard density (Robinson, 2011; Kviklys et al., 2013; Gandev, Dzhuvinov, 2014). The development of orchard systems

Please use the following format when citing the article:

Uselis N., Viškelis J. , Lanauskas J., Liaudanskas M., Janulis V., Kviklys D. 2020. Planting distance affects apple tree growth, fruit yield and quality. Zemdirbyste-Agriculture, 107 (4): 367-372. DOI 10.13080/z-a.2020.107.047 
shows the intensification of the Lithuanian fruit-growing sector (Uselis, 2002).

In the 1950s and 1960s, the yield of vigorous apple trees with seedling rootstocks increased from 6 to $28 \mathrm{t} \mathrm{ha}^{-1}$, when planting density was increased from $8 \times$ $8 \mathrm{~m}\left(156\right.$ trees $\left.\mathrm{ha}^{-1}\right)$ to $6 \times 3 \mathrm{~m}\left(555\right.$ trees $\left.\mathrm{ha}^{-1}\right)$. In such orchards, up to $44 \%$ of the fruit was $55 \mathrm{~mm}$ in diameter and larger. Decreasing planting distances of vigorous fruit trees decreased yields (Kalkys, 1970; Armolaitis, 1973). In the 1980s, it was found in an apple tree orchard on clonal rootstocks that by increasing planting density, the yield per unit area of young fruit trees could be increased. Apple trees with semi-vigorous rootstock MM.106, planted at $5 \times 2 \mathrm{~m}\left(1000\right.$ tree $\left.^{-1}\right)$, gave a yield of $37 \mathrm{t} \mathrm{ha}^{-1}$ in the $9^{\text {th }}-10^{\text {th }}$ leaf (Kviklys, 1987). An apple tree orchard with dwarf rootstock B.396 (3 338 tree ha ${ }^{=1}$ ) gave an average yield of $33 \mathrm{t} \mathrm{ha}^{-1}$ in the $4^{\text {th }}-7^{\text {th }}$ leaf. As much as $91 \%$ of the fruits of this harvest were $70 \mathrm{~mm}$ and larger in diameter (Uselis, 2002). In later years, it was established that orchard design had a great impact on the fruit tree vigour, productivity, yield and fruit quality of cultivars 'Spartan' and 'Sinap Orlovskij' apple trees on rootstock B.396. Sparsely planted trees were the most vigorous and gave the highest yield per plant. When plant density increased 2-4 times, the yield per tree decreased 1.5-2.5 times. The highest yields per unit area were found in high-density (3.380-5.000 trees ha-1) orchards (Uselis, 2003).

The fruit quality differed significantly between the two cultivars. 'Sinap Orlovskij' apples produced very large fruits, and their size did not depend entirely on planting density, whereas 'Spartan' apples were smaller in a high-density planting system (Uselis, 2003). Planting density influences light interception, especially in an older orchard, and this affects some fruit quality traits (Lordan et al., 2018). Low light penetration (less than $50 \%$ of the total incident energy) in the canopy can compromise fruit quality (Musacchi, Serra, 2018). With increasing tree height, the light penetration into the internal parts of the canopy decreased, especially in the lower canopy (Choi et al., 2014). So, fruit quality should strongly depend on the position of the fruit in the canopy. In the lower and upper parts of the fruit tree, these indicators may vary significantly.

Reports of the studies on orchard systems usually present results from 1- to 10-year plantings. Information on tree vegetative performance and productivity in later stages is lacking. Therefore, the aim of the current study was to evaluate the influence of planting density on the growth, fruit yield and quality of dwarf apple trees in a full bearing (15-18 years old) orchard.

\section{Materials and methods}

The impact of planting distance on apple tree (Malus $\times$ domestica Borkh) growth, yield parameters and fruit quality was evaluated in a 15 - to 18-year-old orchard, established in 2015-2018 at the Institute of Horticulture, Lithuanian Research Centre for Agriculture and Forestry. The study involved the commercially important northern climate apple cultivar 'Auksis' on one of the most valuable dwarf rootstocks P 60 (Kviklys et al., 2012).

The following planting distances and tree training systems were tested: 1) fruit trees spaced at $3 \times$ $1.50 \mathrm{~m}\left(2222\right.$ trees $\left.^{-1}\right)$, trained as spindles, 2) fruit trees spaced at $3 \times 1.25 \mathrm{~m}(2667$ trees ha-1), trained as slender spindles, 3) fruit trees spaced at $3 \times 1.00 \mathrm{~m}$ (3 333 trees $\left.\mathrm{ha}^{-1}\right)$, trained as slender spindles, and 4) fruit trees spaced at $3 \times 0.75 \mathrm{~m}$ ( 4444 trees $\left.\mathrm{ha}^{-1}\right)$, trained as super spindles. The fruit trees were pruned in March in each year of the experiment, maintaining the canopy shape provided for each planting scheme.

Apple trees were planted in a randomized block design, with three replicates and five trees per plot. The soil in the orchard was Epicalcari-Endohypogleyic Cambisol (WRB, 2014), heavy clay loam containing $2.8 \%$ of humus, $139 \mathrm{mg} \mathrm{kg}^{-1} \mathrm{P}, 158 \mathrm{mg} \mathrm{kg}^{-1} \mathrm{~K}, 5098 \mathrm{mg}$ $\mathrm{kg}^{-1} \mathrm{Ca}$ and $1172 \mathrm{mg} \mathrm{kg}^{-1} \mathrm{Mg}$, with $\mathrm{pH} 7.3$ (in $1 \mathrm{~mol} \mathrm{~L}^{-1}$ $\mathrm{KCl}$ extract). The orchard was fertilized annually at a rate of $\mathrm{N}_{50} \mathrm{~K}_{80}$. Nitrogen fertilizer in the form of $\mathrm{NH}_{4} \mathrm{NO}_{3}$ was applied in early spring and $\mathrm{KCl}$ - in late autumn. Weeds in the rows were controlled with glyphosatebased herbicides. Frequently mown grass was kept in the alleyways. Pest and disease control was carried out according to the rules of integrated plant protection (Valiuškaitè et al., 2017).

Apple trees growth was evaluated according to the trunk diameter, shoot number, shoot length and weight of pruned branches. Trunk diameter was measured $30 \mathrm{~cm}$ above the soil surface and converted to the trunk crosssectional area (TCSA) in $\mathrm{cm}^{2}$. Annual shoot number and total $(\mathrm{m})$ and average shoot length $(\mathrm{cm})$ were evaluated for every tree at the end of vegetation periods. Weight of pruned branches $(\mathrm{kg})$ was measured in each experimental plot in March each year. Fruit yield $(\mathrm{kg})$ and mean fruit weight $(\mathrm{g})$ from each tree were recorded at harvest time, and for data analysis, the averages per tree from the experimental plot were calculated. Cumulative yield efficiency was calculated as a ratio of yield per tree to TCSA and expressed in $\mathrm{kg} \mathrm{cm}^{-2}$.

Yield and fruit quality measurements were made at two canopy heights: $0-1.5$ and $1.5-2.5 \mathrm{~m}$.

A sample of 50 fruits per replicate was evaluated for fruit quality parameters. Fruit dry matter content was determined gravimetrically by drying apple samples to a constant weight at $105^{\circ} \mathrm{C}$ temperature. Fruit respiration rate was measured with a gas analyser EASI1 (Absoger, France). Soluble solids were quantified with a digital refractometer PR-32 (Atago Co. Ltd., Japan). Fruit firmness was determined by the texture analyser TA.XTPlus (Stable Micro Systems, UK) using the P/2 probe. Titratable acidity was estimated by titrating with $0.1 \mathrm{~N} \mathrm{NaOH}$ solution to $\mathrm{pH} 8.2$ and was expressed as a percentage of citric acid equivalent. Ascorbic acid was measured by titration using 2,6-dichlorophenolindophenol sodium salt solution (AOAC, 1990 a). Total sugar content was determined using the method described by AOAC (1990 b). Phenolic compounds were determined through the high-performance liquid chromatography (HPLC) method, as described in the article of Liaudanskas et al. (2014). Triterpenic compounds were determined through the HPLC method, as described in the article of Butkevičiūte et al. (2018).

The data on the main traits were subjected to analysis of variance (ANOVA). Significance of differences between rootstock means was estimated through the LSD test at $P<0.05$, when the $F$ value was significant.

\section{Results and discussion}

Apple tree growth. Total length of the shoot from the fruit tree did not change significantly, when the distance between trees in a row was decreased from 1.5 to $1.0 \mathrm{~m}$. Reduction of planting distance to $0.75 \mathrm{~m}$ resulted in significantly the smallest total length of the shoot (Table 1). 
Table 1. Effect of planting distances on apple tree growth parameters (average data 2015-2018)

\begin{tabular}{|c|c|c|c|c|c|c|c|c|}
\hline \multirow{2}{*}{$\begin{array}{l}\text { Planting } \\
\text { distance } \\
\mathrm{m}\end{array}$} & \multicolumn{2}{|c|}{$\begin{array}{c}\text { Total } \\
\text { shoot length }\end{array}$} & \multicolumn{2}{|c|}{$\begin{array}{l}\text { Shoot } \\
\text { number }\end{array}$} & \multirow{2}{*}{$\begin{array}{c}\begin{array}{c}\text { Average shoot } \\
\text { length }\end{array} \\
\mathrm{m}\end{array}$} & \multirow{2}{*}{$\begin{array}{l}\begin{array}{c}\text { Trunk cross- } \\
\text { sectional area }\end{array} \\
\mathrm{cm}^{2}\end{array}$} & \multicolumn{2}{|c|}{$\begin{array}{c}\text { Weight of } \\
\text { pruned branches }\end{array}$} \\
\hline & $m$ tree $^{-1}$ & $\mathrm{~km} \mathrm{ha}^{-1}$ & tree & thousand $\mathrm{ha}^{-1}$ & & & $\mathrm{~kg}$ tree $^{-1}$ & $\mathrm{t} \mathrm{ha}^{-1}$ \\
\hline $3 \times 1.50$ & $33.5 \mathrm{a}^{*}$ & $74.6 \mathrm{~b}$ & $91.9 \mathrm{a}$ & $204.2 \mathrm{~b}$ & $0.44 \mathrm{~b}$ & $73.4 \mathrm{a}$ & $2.53 \mathrm{a}$ & $5.57 \mathrm{~b}$ \\
\hline $3 \times 1.25$ & $29.2 \mathrm{a}$ & $78.0 \mathrm{~b}$ & $77.7 \mathrm{~b}$ & $207.1 \mathrm{~b}$ & $0.46 \mathrm{~b}$ & $66.3 \mathrm{ab}$ & $2.00 \mathrm{~b}$ & $5.40 \mathrm{~b}$ \\
\hline $3 \times 1.00$ & $33.2 \mathrm{a}$ & $110.9 \mathrm{a}$ & $76.8 \mathrm{~b}$ & $256.0 \mathrm{ab}$ & $0.54 \mathrm{a}$ & $56.8 \mathrm{bc}$ & $2.31 \mathrm{ab}$ & $7.72 \mathrm{a}$ \\
\hline $3 \times 0.75$ & $21.6 \mathrm{~b}$ & $96.6 \mathrm{ab}$ & $61.1 \mathrm{c}$ & $271.5 \mathrm{a}$ & $0.45 \mathrm{~b}$ & $46.6 \mathrm{c}$ & $1.57 \mathrm{c}$ & $7.07 \mathrm{a}$ \\
\hline
\end{tabular}

*-differences significant at $p<0.05$

The total length of shoots per unit area was the smallest in the most sparsely planted orchard. When planting density was increased, this indicator tended to increase. Significantly the greatest total shoot length was at a planting density of 3333 trees ha ${ }^{-1}$. In this treatment, the average shoot length was also the highest (Table 1). When the tree density in the row increased from 1.50 to $1.00 \mathrm{~m}$, plant competition caused shoot elongation, but when tree density increased further, the total and average shoot length was reduced. Vegetative growth and flower bud formation are considered antagonistic processes (Koutinas et al., 2010). The reduction of vegetative growth means lower consumption of carbohydrates for shoot production. Therefore, carbohydrates should be utilized more efficiently for fruit development. As the density of the orchard increased, the number of shoots per fruit tree decreased significantly and was the lowest in the orchard with the highest tree density (Table 1).

The number of shoots per unit area tended to increase and was significantly the largest in the densest planting system. Similar trends were observed in the weight of pruned branches. The highest number of branches was found to be pruned from sparsely growing apple trees. With increasing fruit tree density, the weight of pruned branches decreased, and significantly the smallest amount was removed from the densest plantings. The largest weight of branches per plot was pruned in the treatments, where the distance between fruit trees in a row was 1.00 and $0.75 \mathrm{~m}$.

The effect of planting distances on the growth of fruit trees is clearly illustrated by the TCSA: the denser the trees, the smaller their TCSA. In other studies, very dense planting also suppressed growth of shoots and trunk (Licznar-Małańczuk, 2004).

Generative apple tree development and yield. Sparsely spaced fruit trees formed the highest number of flower clusters. As the planting density increased, fruit trees produced fewer flower clusters, and significantly the least flowering was recorded in the most densely planted treatment (Table 2). When tree density in the row increased from 1.50 to $1.00 \mathrm{~m}$, the number of flower clusters remained the same. When planting distance between the fruit trees reached $0.75 \mathrm{~m}$, the number of flower clusters per unit area was significantly higher.

Table 2. Effect of planting distances on apple tree generative development and productivity (average data 2015-2018)

\begin{tabular}{|c|c|c|c|c|}
\hline \multirow{2}{*}{$\begin{array}{l}\text { Planting distance } \\
\mathrm{m}\end{array}$} & \multicolumn{2}{|c|}{ Number of flower clusters } & \multirow{2}{*}{$\frac{\text { Yield }}{\mathrm{kg} \mathrm{tree}^{-1}}$} & \multirow{2}{*}{$\frac{\text { Yield }}{\mathrm{t} \mathrm{ha}^{-1}}$} \\
\hline & tree $^{-1}$ & thousands $\mathrm{ha}^{-1}$ & & \\
\hline $3 \times 1.50$ & $147.8 \mathrm{a}^{*}$ & $328.3 \mathrm{~b}$ & $23.9 \mathrm{a}$ & $52.6 \mathrm{~b}$ \\
\hline $3 \times 1.25$ & $111.7 \mathrm{ab}$ & $297.9 \mathrm{~b}$ & $22.1 \mathrm{ab}$ & $59.0 \mathrm{ab}$ \\
\hline $3 \times 1.00$ & $95.2 \mathrm{~b}$ & $317.2 \mathrm{~b}$ & $15.7 \mathrm{~b}$ & $52.2 \mathrm{~b}$ \\
\hline $3 \times 0.75$ & $87.9 \mathrm{~b}$ & $390.8 \mathrm{a}$ & $15.3 \mathrm{~b}$ & $68.0 \mathrm{a}$ \\
\hline
\end{tabular}

* - differences significant at $p<0.05$

Similar results were established for yield. The yield of sparsely spaced fruit trees was very similar. When the fruit trees were planted more densely in rows to 1.00 or $0.75 \mathrm{~m}$, they yielded significantly less fruit (Table 2). Conversely, the highest yield per plot was in the densest planting system. Fruit trees spaced at $3 \times 1.25 \mathrm{~m}$ were slightly less productive. Significantly less yield per plot was observed, when the planting distance between fruit trees in the row was 1.00 or $1.50 \mathrm{~m}$. Other researchers also reported that increasing tree density results in higher yield per hectare but lower yield per tree (Robinson, $2007 \mathrm{~b}$ ).
This trend becomes evident as soon as the apple trees begin to compete with each other (Eccher, Granelli, 2006).

Fruit yield and external quality. Fruit trees spaced at $3 \times 1.50 \mathrm{~m}$ produced more than half of the crop up to $1.5 \mathrm{~m}$ in the canopy, where light conditions are usually inferior. Fruit trees grown at $3 \times 1.25 \mathrm{~m}$ and more densely produced a relatively smaller share of fruits in the lower canopy part (Table 3). In dense plantings, a little more than half of the crop ripened in the upper (1.5-2.5 m) canopy part, where conditions for generative bud formation and fruit growth are better.

Table 3. Effect of planting distances on yield distribution and fruit quality in different canopy heights (average data 2015-2018)

\begin{tabular}{|c|c|c|c|c|c|c|}
\hline \multirow{3}{*}{$\begin{array}{l}\text { Planting distance } \\
\mathrm{m}\end{array}$} & \multicolumn{2}{|c|}{ Yield share $\%$} & \multicolumn{2}{|c|}{ Average fruit weigh g } & \multicolumn{2}{|c|}{ Colour \% } \\
\hline & \multicolumn{6}{|c|}{ Canopy height $\mathrm{m}$} \\
\hline & $0-1.5$ & $1.5-2.5$ & $0-1.5$ & $1.5-2.5$ & $0-1.5$ & $1.5-2.5$ \\
\hline $3 \times 1.50$ & $52.2 \mathrm{a}^{*}$ & $48.2 \mathrm{a}$ & $141.2 \mathrm{a}$ & $159.1 \mathrm{a}$ & $18.0 \mathrm{a}$ & $35.2 \mathrm{a}$ \\
\hline $3 \times 1.25$ & $47.1 \mathrm{a}$ & $52.9 \mathrm{a}$ & $135.6 \mathrm{ab}$ & $152.7 \mathrm{ab}$ & $14.8 \mathrm{~b}$ & $30.7 \mathrm{~b}$ \\
\hline $3 \times 1.00$ & $45.8 \mathrm{a}$ & $54.2 \mathrm{a}$ & $127.3 \mathrm{bc}$ & $149.6 \mathrm{~b}$ & $11.6 \mathrm{c}$ & $28.4 \mathrm{~b}$ \\
\hline $3 \times 0.75$ & $47.4 \mathrm{a}$ & $52.6 \mathrm{a}$ & $123.1 \mathrm{c}$ & $145.1 \mathrm{~b}$ & $11.2 \mathrm{c}$ & $24.9 \mathrm{c}$ \\
\hline Average & $48.1 \mathrm{~A}^{* *}$ & $52.0 \mathrm{~A}$ & $131.8 \mathrm{~B}$ & $151.6 \mathrm{~A}$ & $13.9 \mathrm{~B}$ & $29.8 \mathrm{~A}$ \\
\hline
\end{tabular}

Note. ${ }^{*}$ - the lower-case letters on the same column indicate significant differences between planting distances $(p<0.05) ; * *-$ the capital letters on the same line indicate significant differences between canopy heights $(p<0.05)$. 
During the study, it was observed that fruit quality varied in different parts of the canopy and depended on the orchard density. The average fruit weight was highly dependent on fruit position in the canopy and orchard density. It was found that in the lower part of the canopy, the average fruit weight was the highest in the lowest density system, and it was similar in size in the densest growing apple trees at the upper part (Table 3). In general, the average fruit weight in the upper canopy part was significantly higher than in the lower part, although at the top of the canopy, when the fruit tree density increased, fruit weight tended to decrease. An even more significant decrease in average fruit weight induced by higher planting density was observed in the lower part of the canopy. The smallest apples grew in the lower canopy part of the densest orchard.

In general, there was no difference in yield share between the two canopy heights, whereas bigger and better-coloured fruits were found in the upper canopy.

Training systems did not have a consistent effect on average fruit diameter and weight in the first year of fruiting, but later a trend for lower fruit weight in higher tree density systems was observed (Ozkan et al., 2012). Light contributes better red colour development and some indicators of internal fruit quality (Musacchi, Serra, 2018). In higher density orchards, a large proportion of shade within the canopy is found, and this can result in smaller and less coloured fruits. On the other hand, fruits are more coloured in taller and more open apple trees, even at the highest tree densities (Wagenmakers, Callesen, 1995).

The largest portion $7(0-85 \mathrm{~mm}$ in diameter) of the apples grew in the upper part of the canopy. Their number was generally independent of the density of the fruit trees. There were fewer apples of the abovementioned size in the lower parts of the fruit trees and especially in the densest planted orchard (Table 4). More apples of less than $70 \mathrm{~mm}$ diameter grew in the lower part of the canopy, especially in the densely planted orchard, where their share was significantly higher. The smallest number of apples of this size grew at greater planting distances $(3 \times 1.50$ and $3 \times 1.25 \mathrm{~m})$.

Table 4. Effect of planting distances on fruit diameter in different canopy heights (average data 2015-2018)

\begin{tabular}{|c|c|c|c|c|c|c|}
\hline \multirow{4}{*}{$\begin{array}{l}\text { Planting distance } \\
\mathrm{m}\end{array}$} & \multicolumn{6}{|c|}{ Share of fruits $\%$} \\
\hline & $<70 \mathrm{~mm}$ & $70-85 \mathrm{~mm}$ & $>85 \mathrm{~mm}$ & $<70 \mathrm{~mm}$ & $70-85 \mathrm{~mm}$ & $>85 \mathrm{~mm}$ \\
\hline & \multicolumn{6}{|c|}{ Canopy height $\mathrm{m}$} \\
\hline & \multicolumn{3}{|c|}{$0-1.5$} & \multicolumn{3}{|c|}{$1.5-2.5$} \\
\hline $3 \times 1.50$ & $19.4 b^{*}$ & $31.5 \mathrm{a}$ & $1.04 \mathrm{~d}$ & $8.9 \mathrm{c}$ & $36.9 \mathrm{a}$ & $2.21 \mathrm{~d}$ \\
\hline $3 \times 1.25$ & $19.0 \mathrm{c}$ & $27.8 \mathrm{~b}$ & $0.38 \mathrm{e}$ & $10.2 \mathrm{~d}$ & $40.4 \mathrm{a}$ & $2.33 \mathrm{f}$ \\
\hline $3 \times 1.00$ & $24.4 \mathrm{~b}$ & $21.3 \mathrm{~b}$ & $0.05 \mathrm{~d}$ & $12.8 \mathrm{c}$ & $40.0 \mathrm{a}$ & $1.41 \mathrm{e}$ \\
\hline $3 \times 0.75$ & $28.2 \mathrm{~b}$ & $18.8 \mathrm{c}$ & $0.33 \mathrm{~d}$ & $14.6 \mathrm{c}$ & $38.0 \mathrm{a}$ & $0.01 \mathrm{e}$ \\
\hline Average & $22.8 \mathrm{~b}$ & $24.8 \mathrm{~b}$ & $0.45 \mathrm{e}$ & $11.6 \mathrm{c}$ & $38.8 \mathrm{a}$ & $1.49 \mathrm{~d}$ \\
\hline
\end{tabular}

* - differences significant at $p<0.05$

The data of our study agree with those obtained in Northern Germany reporting that increasing planting density decreases the average fruit diameter slightly (Stehr, 2011). In a similar manner, average fruit colour is inferior at higher densities - decreasing between $5 \%$ and $10 \%$. Srivastava et al. (2017) reported that fruit weight increases with decrease in plant density and fruit size is negatively correlated with the number of fruit trees.

Fruit biochemical composition, physical and physiological properties, bioactive compounds. The effect of planting distance on fruit biochemical composition was insignificant for vitamin $\mathrm{C}$ and acidity content. Vitamin C varied from 8.0 to $8.2 \mathrm{mg} 100 \mathrm{~g} \mathrm{~g}^{-1}$, and acidity content - from $0.3 \%$ to $0.4 \%$ in fresh fruits. Sugar, soluble solids and dry matter content in fresh fruits were significantly higher in apples picked from the most widely planted trees (Table 5).

Sugar content in apples varied from $10.97 \%$ at the narrowest planting distance to $11.90 \%$ at the widest planting distance, soluble solids - from $12.30 \%$ to $13.17 \%$, and dry matter content - from $13.80 \%$ to
$14.80 \%$. Different canopy heights had no significant effect on fruit biochemical composition; however, there was a slight trend for fruits to accumulate more sugars, soluble solids and dry matter at higher canopy locations. Other scientists have also found a trend for denser fruit planting distance to degrade fruit quality with less soluble solids, sucrose, glucose, fructose, sorbitol and malic and citric acids (Nilsson, Gustavsson, 2007; Feng et al., 2014). This is explained by the fact that the leaves in those parts of the canopy from a wider planting distance intercept more light and had a more intense photosynthesis, which resulted in more assimilates to the adjacent fruits.

The planting distance of apple trees had no significant impact on fruit firmness and respiration rate. Slightly firmer fruits were from a lower canopy height (average $431 \mathrm{~N} \mathrm{~cm}^{-2}$ ) compared with a higher canopy height (average $416 \mathrm{~N} \mathrm{~cm}^{-2}$ ). Fruit respiration rate had the same trend: fruits from a lower canopy height had an average respiration rate of $3.77 \mathrm{mg} \mathrm{CO}_{2} \mathrm{~kg} \mathrm{~h}^{-1}$, whereas fruits from a higher canopy height had an average respiration rate of $3.20 \mathrm{mg} \mathrm{CO}_{2} \mathrm{~kg} \mathrm{~h}^{-1}$.

Table 5. Effect of planting distances on fruit biochemical composition in different canopy heights (average data 2015-2018)

\begin{tabular}{ccccccc}
\hline \multirow{2}{*}{$\begin{array}{c}\text { Planting distance } \\
\mathrm{m}\end{array}$} & \multicolumn{3}{c}{ Sugar \% FW } & \multicolumn{2}{c}{ Soluble solids \% FW } & \multicolumn{2}{c}{ Dry matter \% FW } \\
\cline { 2 - 7 } & $0-1.5$ & $1.5-2.5$ & $0-1.5$ & $1.5-2.5$ & $0-1.5$ & $1.5-2.5$ \\
\cline { 2 - 7 } & $11.29 \pm 0.13 \mathrm{ab} *$ & $11.49 \pm 0.19 \mathrm{a}$ & $12.60 \pm 0.20 \mathrm{ab}$ & $12.60 \pm 0.40 \mathrm{a}$ & $13.93 \pm 0.12 \mathrm{ab}$ & $14.37 \pm 0.45 \mathrm{a}$ \\
$3 \times 1.50$ & $11.90 \pm 0.22 \mathrm{a}$ & $11.45 \pm 0.32 \mathrm{a}$ & $13.17 \pm 0.35 \mathrm{a}$ & $12.80 \pm 0.20 \mathrm{a}$ & $14.80 \pm 0.20 \mathrm{a}$ & $14.27 \pm 0.25 \mathrm{a}$ \\
$3 \times 1.25$ & $11.31 \pm 0.21 \mathrm{ab}$ & $11.28 \pm 0.26 \mathrm{a}$ & $12.37 \pm 0.15 \mathrm{~b}$ & $12.53 \pm 0.25 \mathrm{a}$ & $13.8 \pm 0.26 \mathrm{~b}$ & $14.33 \pm 0.31 \mathrm{a}$ \\
$3 \times 1.00$ & $10.97 \pm 0.40 \mathrm{~b}$ & $11.11 \pm 0.29 \mathrm{a}$ & $12.30 \pm 0.36 \mathrm{~b}$ & $12.43 \pm 0.45 \mathrm{a}$ & $14.10 \pm 0.62 \mathrm{ab}$ & $14.00 \pm 0.70 \mathrm{a}$ \\
$3 \times 0.75$ & $11.37 \mathrm{~A}^{* *}$ & $11.33 \mathrm{~A}$ & $12.61 \mathrm{~A}$ & $12.59 \mathrm{~A}$ & $14.16 \mathrm{~A}$ & $14.24 \mathrm{~A}$ \\
\hline Average & &
\end{tabular}

Note. FW - fresh weight; * - the lower-case letters on the same column indicate significant differences between planting distances $(p<0.05) ; * *$ the capital letters on the same line indicate significant differences between canopy heights $(p<0.05)$. 
Phenolic compound content in fruits increased as planting distance decreased at both canopy heights (Table 6). It is known that unfavourable conditions lead to higher stress in fruit trees, and accumulation of phenolic compounds in different parts of fruit trees, including fruits, has been linked to various stress factors (Lattanzio et al., 2006), which agrees with the results of our research.

Table 6. Effect of planting distances on phenols and triterpenes content in fruits in different canopy heights (average data 2015-2018)

\begin{tabular}{cccc}
\hline \multirow{2}{*}{$\begin{array}{c}\text { Planting distance } \\
\mathrm{m}\end{array}$} & \multicolumn{2}{c}{ Phenols mg g-1 DW } \\
\cline { 2 - 4 } & \multicolumn{2}{c}{ Canopy height m } \\
\hline $3 \times 1.50$ & $3.07 \pm 0.15 \mathrm{~b}^{*}$ & $2.91 \pm 0.15 \mathrm{c}$ & $1.5-1.5 \pm 0.61 \mathrm{~b}$ \\
$3 \times 1.25$ & $3.05 \pm 0.15 \mathrm{~b}$ & $3.22 \pm 0.16 \mathrm{bc}$ & $14.90 \pm 0.75 \mathrm{a}$ \\
$3 \times 1.00$ & $3.01 \pm 0.15 \mathrm{~b}$ & $3.51 \pm 0.18 \mathrm{~b}$ & $14.24 \pm 0.71 \mathrm{a}$ \\
$3 \times 0.75$ & $3.49 \pm 0.17 \mathrm{a}$ & $4.03 \pm 0.20 \mathrm{a}$ & $15.23 \pm 0.76 \mathrm{a}$ \\
Average & $3.16 \mathrm{~B}^{* *}$ & $3.42 \mathrm{~A}$ & $16.07 \pm 0.80 \mathrm{a}$ \\
\hline
\end{tabular}

Note. DW - dry weight; * - the lower-case letters on the same column indicate significant differences between planting distances $(p<0.05) ; * *$ - the capital letters on the same line indicate significant differences between canopy heights $(p<0.05)$.

Triterpene content in fruits increased as planting distance decreased, but only at a lower canopy height (Table 5). More triterpenes accumulate in lower and shaded canopy areas (Lv et al., 2015). Differences between shaded and sun-exposed fruits influence the different formation of the wax layer and its structure, which differ in both quantity and quality (Curry, 2008; Tahir et al., 2009), which was also found in our research.

\section{Conclusions}

1. The densest planting systems $(3 \times 1$ and $3 \times 0.75 \mathrm{~m})$ resulted in reduced trunk diameter, shoot number, number of flower clusters and the yield per tree of the apple cultivar 'Auksis' in a full bearing orchard; whereas the values of these parameters were the highest when calculated per unit area.

2. The highest fruit average weight, diameter, the best skin colour, higher sugar, soluble solids and dry matter content were from the most sparsely spaced (3 $\times 1.50$ and $3 \times 1.25 \mathrm{~m}$ ) apple trees, while the poorest external fruit quality was in the densest planting system $(3 \times 0.75 \mathrm{~m})$. A significant trend towards higher accumulation of phenolic and triterpenic compounds in apple fruits was found with decreasing planting distances between the apple trees.

3 . The most sparsely spaced $(3 \times 1.50 \mathrm{~m})$ fruit trees produced more than half of the crop in the lower part of the canopy, whereas in denser planting systems, a larger part of the crop was produced in the upper part of the canopy. In general, external fruit quality in the upper part of the canopy was better and depended less on fruit tree density; however, fruits in the lower part of the canopy had worse quality, which decreased at higher densities.

4. A detailed analysis of the research results suggests that at the full bearing stage, the best productivity and fruit quality of 'Auksis' apple trees on rootstock P 60 was obtained, when fruit trees had been spaced at $3 \times 1.25 \mathrm{~m}$.

\section{Acknowledgments}

This work was supported by a grant from the Research Council of Lithuania, project No. S-MIP-17-8.

Received 24022020

Accepted 24072020

\section{References}

1. AOAC. 1990 (a). Vitamin C (ascorbic acid) in vitamin preparations and juices. Helrich K. (ed.). Official methods of analysis $\left(15^{\text {th }}\right.$ ed.), $1058 \mathrm{p}$.

2. AOAC. 1990 (b). Sucrose in fruits and fruit products Helrich K. (ed.). Official methods of analysis ( $15^{\text {th }}$ ed.), 922 p.
3. Armolaitis E. 1973. The ways of thinning out the orchard and the pruning of densely planted apple-trees. Sodininkyste ir daržininkystè, 14: 39-45 (in Lithuanian).

4. Butkevičiūtė A., Liaudanskas M., Kviklys D., Zymonė K., Raudonis R., Viškelis J., Uselis N., Janulis V. 2018. Detection and analysis of triterpenic compounds in apple extracts. International Journal of Food Properties, 21 (1): 1716-1727. https://doi.org/10.1080/10942912.2018.1506478

5. Choi D. G., Song J., Kang I. 2014. Effect of tree height on light transmission, spray penetration, tree growth, and fruit quality in the slender-spindle system of 'Hongro'/M9 apple trees. Korean Journal of Horticultural Science and Technology, 32 (4): 454-462. https://doi.org/10.7235/hort.2014.13157

6. Curry E. 2008. Effects of 1-MCP applied postharvest on epicuticular wax of apples (Malus domestica Borkh.) during storage. Journal of the Science of Food and Agriculture, 88 (6): 996-1006. https://doi.org/10.1002/jsfa.3180

7. Eccher T., Granelli G. 2006. Fruit quality and yield of different apple cultivars as affected by tree density. Acta Horticulturae, 712: 535-540. https://doi.org/10.17660/ActaHortic.2006.712.66

8. Feng F., Li M., Ma F., Cheng L. 2014. Effects of location within the tree canopy on carbohydrates, organic acids, amino acids and phenolic compounds in the fruit peel and flesh from three apple (Malus $\times$ domestica) cultivars. Horticulture Research, 1: 14019 https://doi.org/10.1038/hortres.2014.19

9. Gandev S., Dzhuvinov V. 2014. Training and pruning of apple and modern trends of development - an overview. Turkish Journal of Agricultural and Natural Sciences, 1 (spec. iss.): 1264-1267.

10. Green S., McNaughton K., Wünsche J. N., Clothier B. 2003. Modeling light interception and transpiration of apple tree canopies. Agronomy Journal, 95 (6): 1380-1387. https://doi.org/10.2134/agronj2003.1380

11. Kalkys P. 1970. The effect of planting distances on growth and fruiting of apple-trees. Sodininkysè ir daržininkysté, 13: 71-79 (in Lithuanian).

12. Koutinas N., Pepelyankov G., Lichev V. 2010. Flower induction and flower bud development in apple and sweet cherry. Biotechnology and Biotechnological Equipment, 24 (1): 1549-1558. https://doi.org/10.2478/V10133-010-0003-9

13. Kviklys A. 1987. Apple-tree clonal rootstocks in a yielding orchard. Sodininkysė ir daržininkystè, 5: 21-30 (in Lithuanian).

14. Kviklys D., Kviklienė N., Bite A., Lepsis J., Univer T., Univer N., Uselis N., Lanauskas J., Buskienè L. 2012. Baltic fruit rootstock studies: evaluation of 12 apple rootstocks in North-East Europe. Horticultural Science, 39 (1): 1-7. https://doi.org/10.17221/29/2011-HORTSCI

15. Kviklys D., Kviklienè N., Bielicki P., Bite A., Lepsis J., Univer T., Univer N., Uselis N., Lanauskas J. 2013. Baltic fruit rootstock studies: evaluation of apple (Malus domestica Borkh.) new rootstocks. Zemdirbyste-Agriculture, 100 (4): 441-446. https://doi.org/10.13080/z-a.2013.100.056

16. Kviklys D., Ceidaite A., Lanauskas J., Uselis N., Samuolienè G. 2016. The effect of rootstock on apple tree bearing stability in a cooler climate. Agricultural and Food Science, 25 (1): 81-88. https://doi.org/10.23986/afsci.53381 
17. Lattanzio V., Lattanzio V. M. T., Cardinali A. 2006. Phytochemistry: role of phenolics in the resistance mechanisms of plants against fungal pathogens and insects. Imperato F. (ed.). Phytochemistry: advances in research. Kerala, India, p. 23-67.

18. Liaudanskas M., Viškelis P., Jakštas V., Raudonis R., Kviklys D., Milašius A., Janulis V. 2014. Application of an optimized HPLC method for the detection of various phenolic compounds in apples from Lithuanian cultivars. Journal of Chemistry, 2014: 542121. https://doi.org/10.1155/2014/542121

19. Licznar-Małańczuk M. 2004. Influence of planting and training systems on fruit yield in apple orchard. Journal of Fruit and Ornamental Plant Research, 98 (12): 97104.

20. Lordan S. J., Francescatto P., Dominguez L. Robinson T. 2018. Long-term effects of tree density and tree shape on apple orchard performance, a 20 year study. Part 1. Agronomic analysis. Scientia Horticulturae, 238: 303-317. https://doi.org/10.1016/j.scienta.2018.04.033

21. Lordan S. J., Gomez M., Francescatto P. Robinson T. 2019. Long-term effects of tree density and tree shape on apple orchard performance, a 20 year study. Part 2. Economic analysis. Scientia Horticulturae, 244: 435-444. https://doi.org/10.1016/j.scienta.2018.03.031

22. Lv Y., Tahir I. I., Olsson M. E. 2015. Factors affecting the content of the ursolic and oleanolic acid in apple peel: influence of cultivars, sun exposure, storage conditions, bruising and Penicillium expansum infection. Journal of the Science of Food and Agriculture, 96 (6): 2161-2169. https://doi.org/10.1002/jsfa.7332

23. Musacchi S., Serra S. 2018. Apple fruit quality: overview on pre-harvest factors. Scientia Horticulturae, 234: 409430. https://doi.org/10.1016/j.scienta.2017.12.057

24. Nilsson T., Gustavsson K. E. 2007. Postharvest physiology of 'Aroma' apples in relation to position on the tree. Postharvest Biology and Technology, 43 (1): 36-46. https://doi.org/10.1016/j.postharvbio.2006.07.011

25. Ozkan Y., Yıldız K., Küëüker E., Ēekiē E., Özgen M., Akēa Y. 2012. Early performance of cv. Jonagold apple on M.9 in five tree training systems. Horticultural Science (Prague), 39: 158-163. https://doi.org/10.17221/35/2012-HORTSCI

26. Platon I., Jacab Z. S., Stānicā F. 2014. Effect of planting system on two apple varieties cultivated in the north-eastern part of Romania. Acta Horticulturae, 1058: 181-191. https://doi.org/10.17660/ActaHortic.2014.1058.20
27. Robinson T. L. 2007 (a). Recent advances and future directions in orchard planting systems. Acta Horticulturae, 732: 367-381.

https://doi.org/10.17660/ActaHortic.2007.732.57

28. Robinson T. L. 2007 (b). Effects of tree density and tree shape on apple orchard performance. Acta Horticulturae, 732: 405-414. https://doi.org/10.17660/ActaHortic.2007.732.61

29. Robinson T. L. 2011. Advances in apple culture worldwide. Revista Brasileira de Fruticultura, 33: 37-47. https://doi.org/10.1590/S0100-29452011000500006

30. Robinson T. L., Hoying S. A., Miranda Sazo M., Fachinello J. C. 2014. Yield, fruit quality and mechanization of the tall spindle apple production system. Acta Horticulturae, 1058: 95-103.

https://doi.org/10.17660/ActaHortic.2014.1058.9

31. Srivastava K. K., Singh D. B., Kumar D. S., Singh S. R., Sharma O. C., Lal S. 2017. Effect of planting densities and varieties on yield and yield associated characters of apple (Malus $\times$ domestica) on semi-dwarfing rootstock. Indian Journal of Agricultural Sciences, 87 (5): 593-596.

32. Stehr R. 2011. Apple crop and fruit quality influenced by low and high planting densities on M.9 and M.27 rootstocks in Northern Germany. Acta Horticulturae, 903: 673-679. https://doi.org/10.17660/ActaHortic.2011.903.93

33. Tahir I. I., Johansson E., Olsson M. E. 2009. Improvement of apple quality and storability by a combination of heat treatment and controlled atmosphere storage. HortScience, 44 (6): 1648-1654

https://doi.org/10.21273/HORTSCI.44.6.1648

34. Uselis N. 2002. Evolution of orchard constructions in Lithuania. Sodininkystè ir daržininkystè, 21 (3): 98-112.

35. Uselis N. 2003. Growth and productivity of dwarf apple trees in bearing orchards of various constructions. Sodininkyste ir daržininkyste, 22 (1): 3-13 (in Lithuanian).

36. Valiuškaitè A., Uselis N., Kviklys D., Lanauskas J., Rasiukevičiūtè N. 2017. 'Effect of sustainable plant protection and apple tree management on fruit quality and yield. Zemdirbyste-Agriculture, 104 (4): 353-358. https://doi.org/10.13080/z-a.2017.104.045

37. Wagenmakers P. S., Callesen O. 1995. Light distribution in apple orchard systems in relation to production and fruit quality, Journal of Horticultural Science, 70 (6): 935-948. https://doi.org/10.1080/14620316.1995.11515369

38. WRB. 2014. World reference base for soil resources. World Soil Resources Reports No. 106. FAO, 192 p.

ISSN 1392-3196 / e-ISSN 2335-8947

Zemdirbyste-Agriculture, vol. 107, No. 4 (2020), p. 367-372

DOI $10.13080 /$ z-a.2020.107.047

\title{
Sodinimo atstumų įtaka obelų augimui, vaisių derliui ir kokybei
}

\author{
N. Uselis ${ }^{1,3}$, J. Viškelis ${ }^{1}$, J. Lanauskas ${ }^{1}$, M. Liaudanskas ${ }^{1,2}$, V. Janulis ${ }^{2}$, D. Kviklys ${ }^{1,4}$ \\ ${ }^{1}$ Lietuvos agrarinių ir miškų mokslų centro Sodininkystės ir daržininkystès institutas \\ ${ }^{2}$ Lietuvos sveikatos mokslų universiteto Farmacijos fakultetas \\ ${ }^{3}$ Vytauto Didžiojo universiteto Žemès ūkio akademija \\ ${ }^{4}$ Norvegijos bioekonomikos mokslinių tyrimų institutas
}

\section{Santrauka}

Sodinimo atstumų ịtakos žemaūgių obelų augimui, produktyvumui ir vaisių kokybei tyrimas buvo atliktas 15-18 metų amžiaus sode, ịveistame Lietuvos agrarinių ir miškų mokslų centro Sodininkystès ir daržininkystès institute. Veislès 'Auksis' obelys su P 60 poskiepiu buvo pasodintos $3 \times 1,5,3 \times 1,25,3 \times 1,00$ ir $3 \times 0,75 \mathrm{~m}$ atstumais. Padidejus sodinimo tankumui, sumažèjo pavienių vaismedžių augimas, generatyvinis vystymasis ir derlius. Priešingi rezultatai buvo gauti šiuos rodiklius vertinant ploto vienete. Derlingumas ir vaisių kokybė buvo matuoti dviejuose vainiko aukščiuose: $0-1,5$ ir 1,5-2,5 m. Vaismedžiu vainiko viršutinėje dalyje vaisiaus vidutinè masẻ ir skersmuo buvo didesni, o spalva intensyvesnè ir mažiau priklausė nuo vaismedžių sodinimo tankumo. Vainiko apatinèje dalyje vaisių kokybė buvo prastesnè, didėjant vaismedžių tankumui ji dar blogèjo. Sodinimo atstumas turèjo esminès įtakos cukraus, tirpių sausujjų medžiagų ir sausųjų medžiagų kaupimuisi - rečiau pasodintame sode šių biocheminių junginių vaisiuose buvo daugiau. Ir atvirkščiai, didesnis fenolinių junginių ir triterpenų kiekis buvo nustatytas vaisiuose, užaugintuose tankiau pasodintame sode. Geriausias veislès 'Auksis' obelų su P 60 poskiepiu derlingumas ir vaisių kokybe pilnai derant gauti $3 \times 1,25 \mathrm{~m}$ atstumu ịveistame sode.

Reikšminiai žodžiai: Malus $\times$ domestica Borkh, sodinimo sistema, vaisių biocheminè sudètis, vaisių spalva. 